\section{The combined effects of Pseudomonas fluorescens CECT 844 and the black truffle co-inoculation on Pinus nigra seedlings}

\author{
José Alfonso Dominguez-Nuñez ${ }^{(1)}$, Marcelina Medina ${ }^{(1)}$, Marta Berrocal- \\ Lobo $^{(1)}$, Analía Anriquez ${ }^{(2)}$, Ada Albanesi ${ }^{(2)}$
}

The inoculation with mycorrhizal fungi and rhizobacteria has been demonstrated to improve the morphology and physiology of seedlings used in the reforestation of Mediterranean areas, as well as to favor the reintroduction of mycorrhizal fungi into such environments. Pinus nigra subsp. salzmannii, currently used in the reforestation of Mediterranean regions, may host an ectomycorrhizal symbiosis with the Ascomycetes fungus Tuber melanosporum Vitt. (black truffle). Previous investigations demonstrated that the inoculation of Pinus halepensis seedlings with the rhizobacterium Pseudomonas fluorescens CECT 844 and $T$. melanosporum improved plant growth and $\mathrm{N}$ absorption, and doubled the rate of mycorrhization of $T$. melanosporum. In the present work, we studied the morphophysiological response of $P$. nigra seedlings grown under well-watered conditions in a nursery to the combined inoculation with $T$. melanosporum and/or $P$. fluorescens CECT 844. Five months after inoculation, growth parameters (seedling height, basal diameter, and shoot and root dry weight), mycorrhizal colonization, water parameters (osmotic potential at both full and zero turgor and modulus of elasticity), and total contents and concentrations of $\mathrm{N}, \mathrm{P}$, and $\mathrm{K}$ were measured in the roots and shoots of seedlings, and the root growth potentials was estimated. The addition of $P$. fluorescens CECT 844 did not significantly improve the mycorrhizal colonization by $T$. melanosporum on $P$. nigra seedling roots. Additionally, $P$. fluorescens inoculation caused few significant improvements in growth and water parameters of seedlings. Moreover, apparently opposing effects on $P$ uptake were observed between the two inoculations. The use of $P$. fluorescens CECT 844 as a Mycorrhizal Helper Bacterium (MHB) through different mechanisms and in different environmental conditions is discussed.

Keywords: Rhizobacteria, Black Truffle, Mycorrhiza, Mycorrhiza Helper Bacteria

\begin{abstract}
Introduction
Water and nutrient availability are the main constraints on plant productivity in semi-arid Mediterranean ecosystems. The preservation of mycoflora diversity depends on the status of plant roots (Marulanda et al. 2006). Forest species in these areas often develop specific strategies to improve their water usage in response to drought (Martínez-Ferri et al. 2000).
\end{abstract}

Several studies have been conducted to improve the quality of seedlings produced in nurseries (Caravaca et al. 2005). Several authors reported that soil amendment with ectomycorrhizal fungi and plant-growth-promoting rhizobacteria (PGPR) increased plant survival and seedling quality, especially in soils with low microbial activity (Chanway 1997, Probanza et al. 2001).

Pseudomonas fluorescens generally shows $\square$ (1) ETSI Mountains, Polytechnic University of Madrid, Av. Ciudad Universitaria s/n, E28040 Madrid (Spain); (2) Faculty of Agronomy and Agroindustries, Nacional University of Santiago de Estero, Av. Belgrano (S) 1912, Santiago del Estero (Argentina)

@ José Alfonso Dominguez-Nuñez (josealfonso.dominguez@upm.es)

Received: Apr 30, 2014 - Accepted: Sep 11, 2014

Citation: Dominguez-Nuñez JA, Medina M, Berrocal-Lobo M, Anriquez A, Albanesi A, 2015. The combined effects of Pseudomonas fluorescens CECT 844 and the black truffle coinoculation on Pinus nigra seedlings. iForest 8: 624-630 [online 2015-01-08] URL:

http: / / www.sisef.it/iforest/contents/?id=ifor1334-007

Communicated by: Gianfranco Minotta

several characteristics of an effective PGPR. It is easily cultivated in vitro, and it colonizes a wide range of ecological niches, including plant rhizospheres (Bolton et al. 1993). Additionally, P. fluorescens genomes are highly diverse, which most likely increases the P. fluorescens survival (Silby et al. 2009). The ecological flexibility of such bacteria allows them to exploit a wide variety of nutrients to adapt to environmental changes for survival. $P$. fluorescens also improves plant growth by producing phytohormones such as auxins (e.g., IAA - Karabaghli et al. 1998). It also has a high capacity for phosphorus solubilization and can produce siderophores (Matthijs et al. 2007).

Despite the very well-known positive effects of $P$. fluorescens on plant survival, only a few studies have been conducted to study its influence on the growth of forest species (Rincón et al. 2008, Ouahmane et al. 2009). We recently demonstrated that the inoculation of Aleppo pine (Pinus halepensis Mill.) with $P$. fluorescens CECT 844 improved the vegetative growth and $\mathrm{N}$ absorption of the $P$. halepensis seedlings (Dominguez et al. 2012).

The use of environmental-friendly natural microbial inocula, such as PGPR or mycorrhizal fungi, is presented in this study as a potential alternative fertilizers. These microorganisms are also beneficial for the maintenance of pre-existing soil microflora, thus contributing to the conservation of soil biodiversity. The amended soil in the nursey increases the vegetative vigor and morphophysiological quality of forest species growth for reforestation purposes (Chanway 1997).

Information regarding the productivity of ectomycorrhizal fungi, their ecological functions and their contributions to the productivity and recovery of altered agroecosystems is increasingly valuable in agroforestry. In Spain, the black truffle (Tuber melanosporum Vitt.) is of substantial economic and social value in rural areas of the Mediterranean (Reyna 2007), although studies on the contributions of T. melanosporum to the growth and physiology of forest plants are scarce (Domínguez-Nuñez 2002). Moreover, the ecological value of such symbiosis in the recovery of Mediterranean ecosystems has not been well characterized.

The inoculation of black truffle-producing species (including Quercus ilex, Quercus faginea and Corylus avellana) with $T$. melanosporum is an important practice, supporting truffle silviculture in natural areas (Reyna 2007). However, preliminary experiments with other non-ascocarp-producing species are only now being initiated. These non-black truffle ascocarp-producing species (including Pinus nigra and Pinus halepensis) are components of mixed stands of natural ecosystems in which the black truffle is 
found (Domínguez et al. 2003, García-Montero et al. 2007). The above pines are also able to form an ectomycorrhizal symbiosis with the black truffle (Pirazzi 1986).

The association of $T$. melanosporum with other indigenous microorganisms may improve plant growth and increase plant nutrient concentrations, thereby protecting the host plant from drought, which is common in the Mediterranean region. The adhesion of and colonization by mycorrhizal helper bacteria (MHB), such as P. fluorescens, on the surfaces of several ectomycorrhizae can improve the symbiotic relationship and the presymbiotic stages, and can benefit the host plant (Frey-Klett et al. 2007, Deveau et al. 2007). In some cases, the co-inoculation of mycorrhizal fungi and $P$. fluorescens may also increase the root colonization by $\mathrm{Pseu}$ domonas (Ouahmane et al. 2009, Dominguez et al. 2012), and the mycorrhizal fungus. In other cases, synergistic effects on the plant growth were observed (Rincón et al. 2007), although co-inoculation did not affect the fungal colonization.

Several authors suggested the presence of $P$. fluorescens to be linked to different stages of ascocarp maturation in the genus Tuber (Citterio et al. 2001, Barbieri et al. 2007), especially in $T$. melanosporum (Rivera et al. 2010).

We previously demonstrated that the inoculation of $P$. halepensis seedlings with $P$. fluorescens CECT 844 rhizobacteria and the black truffle $T$. melanosporum improved plant growth and the $\mathrm{N}$ absorption of seedlings, and that the addition of $P$. fluorescens CECT 844 doubled the mycorrhization rate of $T$. melanosporum (Dominguez et al. 2012). In the present study, inoculations (both combined and single) were performed using T. melanosporum and P. fluorescens CECT 844 in P. nigra seedlings. Seedling growth, water relations and nutrient uptake were studied. Mycorrhizal colonization was analyzed, and the effect of inoculation on the root growth potential of seedlings was also investigated.

Our starting hypothesis was that the combined inoculation of both microorganisms $P$. fluorescens CECT 844 and T. melanosporum - could have synergistic effects and positively influence the $P$. nigra seedling physiology, thereby improving the plant quality at early developmental stages. We also hypothesized that this rhizobacterial strain could behave as a mycorrhizal-helper bacteria on several forest species forming mycorrhizae of black truffle.

\section{Methods}

\section{Plant material}

Seeds of $P$. nigra subsp. salzmannii were collected from Maestrazgo, Castellon, Spain and kept in closed polyethylene bags at $4{ }^{\circ} \mathrm{C}$ until sowing. New containers of Forest Pot $300{ }^{\circledR}$ (Nuevos Sistemas de Cultivo S.L., Girona, Spain), each composed of 50 alveoli, were used. Culture substrates were prepared in mid-May 2011 with vermiculite and Sphagnum light and dark peat mixtures, $\mathrm{pH}$ 6 , with a ratio of $3: 1$ peat:vermiculite, plus $3.7 \%$ (w/v) $\mathrm{CaCO}_{3}$ and $1.8 \%(\mathrm{w} / \mathrm{v}) \mathrm{KOH}$. The peat was previously sterilized in an autoclave at $120^{\circ} \mathrm{C}$ for 2 hours. At sowing, the substrate $\mathrm{pH}$ was close to 8 . The seeds were selected by flotation and immersed in water 24 hours before planting. Prior to sowing, seeds were immersed in $30 \% \mathrm{H}_{2} \mathrm{O}_{2}$ for 15 minutes for disinfection and then washed several times in distilled water. The assays were performed at the E.T.S.I. Mountains, Madrid, Spain. A total of 24 bins (1200 alveoli) were sown. In each alveolus, 3-8 seeds were placed and allowed to germinate, with each socket containing a single pine seedling. Sowing was performed in a greenhouse in May 2011. Seedlings were irrigated daily until soil saturation at a culture temperature between 20 and $30{ }^{\circ} \mathrm{C}$ until inoculation.

\section{Fungal inoculum}

The black truffle inoculum was prepared from ascocarps collected in February 2011 in Molina de Aragón (Guadalajara, Spain). T. melanosporum fruiting bodies were selected, superficially cleaned and flame-sterilized. The samples were then stored in closed polyethylene bags at $4{ }^{\circ} \mathrm{C}$ until the liquid spore inoculum was prepared several days before inoculation. The fruiting bodies were ground, diluted in distilled water and stored at $4{ }^{\circ} \mathrm{C}$ until inoculation. The fungal inoculum was estimated to contain approximately $3.4 \times 10^{4}$ spores $\mathrm{ml}^{-1}$.

\section{Bacterial cultures and inoculation assays}

The lyophilized inoculum of $P$. fluorescens CECT 844 was obtained from the CECT (Spanish Type Culture Collection) at the University of Valencia and stored at 10-15 ${ }^{\circ} \mathrm{C}$ until use. The lyophilized bacteria were pre-incubated for recovery in a standard liquid nutrient medium suitable for the growth of $P$. fluorescens ( $1 \mathrm{~g}$ meat extract, $2 \mathrm{~g}$ yeast extract, $5 \mathrm{~g}$ peptone, $5 \mathrm{~g} \mathrm{NaCl}$ and $1 \mathrm{~L}$ distilled water, $\mathrm{pH}$ 7.2) and maintained at $28^{\circ} \mathrm{C}$ for $12 \mathrm{~h}$ at $200 \mathrm{rpm}$. A second culture was grown at $30{ }^{\circ} \mathrm{C}$ for $12 \mathrm{~h}$ before inoculation. The inoculum was prepared at the final concentration of $3 \times 10^{7} \mathrm{CFU} \mathrm{ml} l^{-1}$ as estimated by plate counting.

We used a 4-level univariate design (inoculation of $P$. fluorescens CECT 844 [Ps], $T$. melanosporum [T], $T$. melanosporum $x P$. fluorescens CECT 844 [T $\times$ Ps] and control) distributed into 6 randomized blocks $(1 \times 4$ $\times 6$ ) with 200 plants per block (4 containers with 50 plants/container).
The inoculum of $P$. fluorescens CECT 844 was applied in two steps separated by 7 days (July 22 and 29, 2011). Half of the seedlings were inoculated with $10 \mathrm{ml} \mathrm{plant}^{-1}(5+5 \mathrm{ml}$, $3 \times 10^{8} \mathrm{CFU}$ plant $\left.^{-1}\right)$. The inoculum of $T$. melanosporum was applied on July 27, 2011. Half of the seedlings were inoculated with $5 \mathrm{~g}$ fresh carpophore $/ 20 \mathrm{ml}$ distilled water/plant $\left(6.8 \times 10^{5}\right.$ spores plant $\left.^{-1}\right)$. After the second inoculation with $P$. fluorescens CECT 844, the seedlings were removed from the greenhouse and watered daily until saturation. The $\mathrm{HOBO}^{\circledR}$ data logger was used to measure the temperature and relative humidity. The plants were then maintained in an outdoor nursery at an average temperature of $2-30{ }^{\circ} \mathrm{C}$ and relative humidity $40-80 \%$.

\section{Pressure-volume curves and water parameter analysis}

In November 2011, pressure-volume (PV) curves were built as described by Tyree \& Hammel (1972) and Robichaux (1984) using the stem water potential measured by a Scholander pressure chamber (Scholander et al. 1965). From each pressure-volume curve, the following three parameters were calculated: the osmotic potential at saturation $\left(\Psi \pi_{\text {full }}\right)$, the osmotic potential at the turgor loss point $\left(\Psi \pi_{0}\right)$ and the modulus of elasticity $\left(E_{\max }-\right.$ Cheung et al. 1975, Jones \& Turner 1980, Tyree \& Jarvis 1982, Bowman $\&$ Roberts 1985). Twelve randomly chosen plants per treatment were analyzed (1 PV curve per plant; two plants per block). The seedlings inoculated with $T$. melanosporum (treatments $[\mathrm{T}]$ and $[\mathrm{T} \times \mathrm{Ps}]$ ) were later analyzed to confirm the presence of the mycorrhizal fungus.

\section{Plant vegetative growth and mycorrhizal colonization measures}

Eighteen plants per treatment (three plants per block) were randomly selected in late November 2011. The height and diameter of each plant was measured. We analyzed the colonization by the mycorrhizal fungi by characterizing and identifying the mycorrhizae (Agerer 2012). Subsequently, the mycorrhizal counts of $T$. melanosporum and other naturally occurring mycorrhizal fungi were determined on the total roots as follows. The root ball of each plant was submerged in water to clean the roots by removing most of the substrate. Roots were then chopped into $1-$ to $2-\mathrm{cm}$ pieces that were cleaned, rinsed in distilled water and placed into a Petri dish with water for analysis. The percentage and number of root tips in both the inoculated and non-inoculated plants were calculated. Then, the dry weight of shoots and roots was measured for each sample after oven-drying at $65-70{ }^{\circ} \mathrm{C}$ for $48 \mathrm{~h}$.

\section{Plant nutrition attributes}

In November 2011, concentration and con- 
tent of key nutrients (nitrogen, phosphorus, and potassium) assimilated in the shoots and roots of seedlings were analyzed. Random samples of 36 plants per treatment (6 plants per block) were divided into three groups. The aerial portion and the roots of each seedling were regrouped, cleaned and dried in an oven at $65-70{ }^{\circ} \mathrm{C}$ for at least 48 hours. The tissue was finely ground and homogenized by a pestle. The N, P and $\mathrm{K}$ analyses were performed using a Continuous Flow Analyzer Skalar SAN++ (Skalar Analytical B.V., Breda, The Netherlands) after Kjeldahl digestions in $\mathrm{H}_{2} \mathrm{SO}_{4}$ following the manufacturer's instructions.

\section{Root growth potential}

The root growth potential, i.e., the ability of the plant roots to initiate and extend further in a given time period under optimal growth conditions (Ritchie 1985), was determined by random sampling 18 plants per treatment ( 3 plants per block) on March 16 2012. The height and basal diameter of each plant were measured. Subsequently, each plant with its root ball was carefully transplanted to a 3-L prismatic pot filled with inert white perlite. The pots were placed randomly in the greenhouse in E.T.S.I. Mountains and allowed to grow under optimal growth conditions for 30 days (Simpson \& Ritchie 1997). The plants were irrigated by maintaining the substrate at saturation. The environmental conditions were monitored in the greenhouse, and the temperature was set to $22{ }^{\circ} \mathrm{C}$. The $\mathrm{HOBO}^{\circledR}$ data logger was used to measure the temperature and relative humidity. During the analysis, the average air temperature was maintained between 13 and $28{ }^{\circ} \mathrm{C}$, with a relative humidity between 25 $85 \%$. After one month, each plant was carefully removed, and the new roots (distinguishable by their distinct color and greater thickness) greater than $1 \mathrm{~cm}$ were counted, and the total length of new roots measured for each plant.

\section{Data analysis}

All of the statistical analyses were performed using the software package STATGRAPHICS Plus ${ }^{\circledR}$ (StatPoint Technologies Inc., Warrenton, Virginia, USA). Analysis of variance (ANOVA) for the proposed parameters and the Duncan's mean comparison test were performed using a confidence level of 5 $\%$. In the case of non-homogeneous variances, the non-parametric Kruskal-Wallis test was applied. For the analysis of the root growth potential, the height and the diameter were selected as covariates. Similar results were obtained for each covariate, therefore only results obtained using the height covariate are presented.

\section{Results and discussion}

\section{Seedling growth and mycorrhizal colonization}

Several authors argued that the microflora associated with Tuber sp. are stable and selectively represented by the genus Pseudomonas and the aerobic spore-forming bacteria actinomycetes and rhizobacteria (Citterio et al. 2001, Barbieri et al. 2007). Rivera et al. (2010) found that the predominant species in the ascocarps of T. melanosporum was $P$. fluorescens.

The adhesion of and colonization by MHB (which are metabolically active) at the mycorrhizal surface can affect and improve the symbiotic relationship and the pre-symbiotic stages (Frey-Klett et al. 2007, Deveau et al. 2007). The stimulatory effects of $P$. fluorescens and ectomycorrhizal fungi when grown together have been alreay reported (Rincón et al. 2005, Deveau et al. 2007). Additionally, MHB may be beneficial to certain fungi but may adversely affect others (Tarka \& Frey-Klett 2008). However, MHB seem to be fungus-specific and not plant-specific (Garbaye \& Duponnois 1993).

In this study, $\mathrm{CO}_{3} \mathrm{Ca}$ and $\mathrm{KOH}$ were added to the substrate where $P$. nigra seedlings were grown. Under such conditions, no significant improvement was found in the colonization by black truffle of the roots of $P . n i$ gra seedlings by $P$. fluorescens CECT 844 inoculation (Tab. 1). However, we have demonstrated that $P$. fluorescens CECT 844 can facilitate the formation and establishment of $T$. melanosporum ectomycorrhizae in $P$. halepensis seedlings under non-optimal soil $\mathrm{pH}$ conditions, when calcium carbonate is not added to the growing peat substrate (Dominguez et al. 2012). According to Garbaye \& Duponnois (1993), MHB are not plant-specific, but they are clearly selective in their interactions with various fungal species, being therefore fungus-specific. Because $P$. fluorescens CECT 844 may be a MHB not specific to Pinus sp., we hypothesize that $P$. fluorescens CECT 844 as MHB could significantly increase the colonization by $T$. melanosporum only when the environment (soil) is unsuitable for fungal growth, as suggested by Brule et al. (2001) for the fungus Laccaria bicolor. Under unfavorable conditions, it may be also hypothesized that the fungus is not able to prepare a suitable environment to promote mycorrhization, e.g., potentially increasing the mycorrhizal root tips or creating nutritional stress to promote the fungus-plant symbiosis.

In this study, the effect of $P$. fluorescens on the growth of $P$. nigra seedlings was only significant for the shoot dry weight when $P$. fluorescens was co-inoculated with T. melanosporum (Tab. 1). P. fluorescens is a plant growth stimulator that efficiently promotes seed germination, accelerates growth in the early stages, induces root initiation, enhances the formation of roots and root hairs, facilitates root regeneration and helps control pathogens in some forest species (Heinonsalo et al. 2004). These effects have been observed specifically in P. halepensis inoculated with $P$. fluorescens Aur6 (Rincón et al. 2008). However, the isolated effects of $P$. fluorescens CECT 844 on the root initiation

Tab. 1 - Water relation parameters, growth parameters, mycorrhizal colonizations, and root growth potential of Pinus nigra seedlings. (C): control; (Ps): Pseudomonas fluorescens CECT 844; $(T)$ : Tuber melanosporum. ( $\Psi \pi_{\text {full }}$ ): osmotic potential at full turgor; $\left(\Psi \pi_{0}\right)$ : osmotic potential at zero turgor; $\left(E_{\max }\right)$ : modulus of elasticity near full turgor. (Total): number of total root tips/plant; Total number and length of new roots/plant; covariate using the height parameter. Means and standard errors are reported. $\mathrm{N}=12$ (water relations); $\mathrm{N}=18$ (growth, mycorrhizal colonization and root growth potential parameters). Values in the same row and labeled with different letters differ significantly $(\mathrm{p}<0.05)$ according to the Duncan's test.

\begin{tabular}{|c|c|c|c|c|c|}
\hline Group & Treatment & C & Ps & $T$ & $T \times P S$ \\
\hline \multirow{3}{*}{$\begin{array}{l}\text { Water relation } \\
\text { parameters }\end{array}$} & $\Psi \pi_{\text {full }}(\mathrm{MPa})$ & $0.70 \pm 0.09^{\mathrm{a}}$ & $0.76 \pm 0.06^{\mathrm{a}}$ & $0.82 \pm 0.09^{\mathrm{a}}$ & $0.70 \pm 0.10^{a}$ \\
\hline & $\Psi \pi_{0}(\mathrm{MPa})$ & $0.99 \pm 0.13^{\mathrm{a}}$ & $1.18 \pm 0.13^{\mathrm{a}}$ & $1.28 \pm 0.15^{\mathrm{a}}$ & $1.11 \pm 0.13^{\mathrm{a}}$ \\
\hline & $E_{\max }(\mathrm{MPa})$ & $6.92 \pm 1.38^{\mathrm{a}}$ & $7.33 \pm 1.13^{\mathrm{a}}$ & $4.56 \pm 0.96^{\mathrm{a}}$ & $7.54 \pm 1.39^{\mathrm{a}}$ \\
\hline \multirow[t]{4}{*}{ Growth } & Height $(\mathrm{cm})$ & $6.64 \pm 0.32^{\mathrm{a}}$ & $6.83 \pm 0.14^{\mathrm{a}}$ & $7.08 \pm 0.28^{a}$ & $6.50 \pm 0.43^{a}$ \\
\hline & Basal diameter $(\mathrm{mm})$ & $1.36 \pm 0.07^{\mathrm{a}}$ & $1.38 \pm 0.07^{\mathrm{a}}$ & $1.44 \pm 0.05^{\mathrm{a}}$ & $1.43 \pm 0.05^{\mathrm{a}}$ \\
\hline & Shoot $(\mathrm{g})$ & $0.13 \pm 0.01^{\mathrm{b}}$ & $0.14 \pm 0.01^{\mathrm{ab}}$ & $0.16 \pm 0.02^{a b}$ & $0.16 \pm 0.01^{a}$ \\
\hline & Root $(\mathrm{g})$ & $0.13 \pm 0.01^{\mathrm{a}}$ & $0.14 \pm 0.01^{\mathrm{a}}$ & $0.14 \pm 0.01^{\mathrm{a}}$ & $0.12 \pm 0.01^{\mathrm{a}}$ \\
\hline \multirow{2}{*}{$\begin{array}{l}\text { Mycorrhizal } \\
\text { colonization }\end{array}$} & $\mathrm{T}(\%)$ & $0^{\mathrm{b}}$ & $0^{\mathrm{b}}$ & $24 \pm 3^{a}$ & $27 \pm 3^{a}$ \\
\hline & Total (n/plant) & $99 \pm 4^{b}$ & $102 \pm 4^{b}$ & $166 \pm 13^{\text {a }}$ & $165 \pm 13^{\text {a }}$ \\
\hline \multirow{2}{*}{$\begin{array}{l}\text { Root growth } \\
\text { potential }\end{array}$} & New roots (n/plant) & $7.34 \pm 0.75^{\mathrm{a}}$ & $7.79 \pm 0.75^{\mathrm{a}}$ & $7.49 \pm 0.75^{\mathrm{a}}$ & $6.81 \pm 0.75^{a}$ \\
\hline & New roots (cm/plant) & $7.49 \pm 0.84^{\mathrm{a}}$ & $6.55 \pm 0.84^{\mathrm{a}}$ & $7.18 \pm 0.84^{\mathrm{a}}$ & $6.15 \pm 0.84^{\mathrm{a}}$ \\
\hline
\end{tabular}



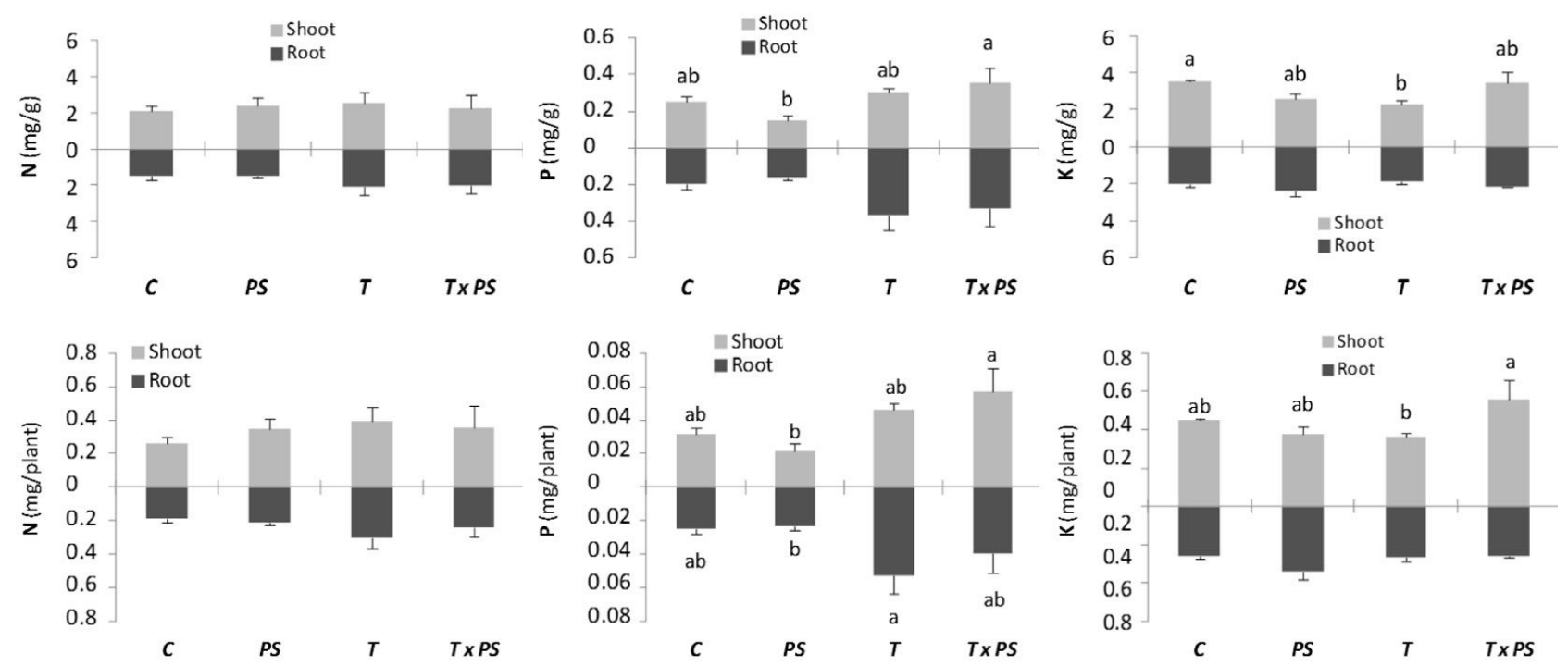

Fig. 1 - Nutrients concentrations and contents of Pinus nigra seedlings. (C): control; (Ps): Pseudomonas fluorescens CECT 844; (T): Tuber melanosporum. Bars represent the standard error $(\mathrm{N}=3)$. Columns with same color and different letters differ significantly $(\mathrm{p}<0.05)$ accor ding to the Duncan's test.

(Root Growth Potential test) were not apparent in this or previous studies (Tab. 1 . Dominguez et al. 2012), though the inoculation of this strain have been observed to significantly improve other growth parameters.

In the present study, the inoculation of $T$. melanosporum significantly increased the total number of root tips in both the simple inoculation $[\mathrm{T}]$ and the co-inoculation $[\mathrm{T} \times$ Ps] treatments. However, the fungus did not significantly increase the root dry weight, indicating that the mycorrhizal fungus $T$. melanosporum increased the root branching in $P$. nigra seedlings without affecting the root biomass production. Splivallo et al. (2009) suggested that this could be facilitated by the production of phytohormones by the fungus. In a similar study on $P$. halepensis grown with no $\mathrm{CaCO}_{3}$ or other $\mathrm{pH}$ correctors in the substrate Domínguez et al. $(2008,2012)$ observed that the inoculation of T. melanosporum did not significantly increase the total production of root tips. Such results suggest that the fungus could increase the total production of root tips (both mycorrhizal and non-mycorrhizal) only in soils with available $\mathrm{CaCO}_{3}$ or with a high $\mathrm{pH}$. However, it seems that inoculation with $P$. fluorescens (in combination with $T$. melanosporum or alone) does not significantly affect the total production of root tips (Tab. 1).

These inoculations did not cause the regeneration of new roots the following spring (root growth potential), in contrast to observations made in previous studies (Karabaghli et al. 1998, Heinonsalo et al. 2004); this may suggest different effects of different strains of Pseudomonas fluorescens on root regeneration. Furthermore, we did not observe any positive synergistic effects of the fungusMHB partnership on root growth or the re- generation of new roots. However, increasing the number of plants sampled and/or the duration of the radical regeneration trial could enhance the appearance of treatment effects in the seedlings.

\section{Nutrient uptake}

In our study, the co-inoculation treatment $[\mathrm{T} \times \mathrm{Ps}]$ significantly increased the concentration and total $\mathrm{P}$ content in the shoot as compared with the $[\mathrm{Ps}]$ inoculation treatment. Additionally, the $[\mathrm{T} \times \mathrm{Ps}]$ inoculation significantly increased the $\mathrm{K}$ content in the shoot compared with that of the $[\mathrm{T}]$ inoculation. Moreover, the T. melanosporum [T] inoculation significantly reduced the $\mathrm{K}$ concentration in the shoot compared with that of the control, and significantly increased the $\mathrm{P}$ content compared with that of the [Ps] inoculation (Fig. 1).

Improvement of host plant vigor by mycorrhizae is often observed under limited nutrient supply (Smith \& Read 1997). Rincón et al. (2007) observed different effects of ectomycorrhizal fungi on the nutrient uptake in seedlings of $P$. halepensis, as a likely consequence of nutritional demands that were dependent on the fungal species (Olsson et al. 2002). Also, in our previous studies on $T$. melanosporum, inoculation was shown to improve growth and nutrition, particularly in $P$. halepensis seedlings (Domínguez et al. 2008, 2012).

In Mediterranean calcareous soils, $\mathrm{P}$ is a limiting nutrient for early growth of $P$. halepensis (Sardans et al. 2006), and the $\mathrm{Ca}$ availability in the substrate can hinder the $\mathrm{P}$ and $\mathrm{K}$ uptake from the soil. On the other hand, P. fluorescens has a high capacity for phosphorus solubilization. However, in this study such beneficial effect was not obser- ved, despite seedlings were produced under limited nutrient availability (no added fertilizer) in the nursery. Moreover, the two inoculations apparently caused opposite effects on the $\mathrm{P}$ and $\mathrm{K}$ absorption by seedlings. Dominguez et al. (2012) observed that $P$. fluorescens CECT 844 inoculation may decrease the $\mathrm{P}$ and $\mathrm{K}$ uptake in $P$. halepensis seedlings co-inoculated with $T$. melanosporum and growing on a substrate with no $\mathrm{CaCO}_{3}$. However, in the present study, $\mathrm{P}$ uptake of $P$. nigra seedlings grown on substrate with $\mathrm{CaCO}_{3}$ and co-inoculated with $T$. melanosporum was not significantly affected by $P$. fluorescens inoculation. Contrastingly, $\mathrm{K}$ content of the mycorrhizal seedlings coinoculated with $T$. melanosporum was significantly improved by $P$. fluorescens inoculation. All the above result suggests that $T$. melanosporum and P. fluorescens inoculations can cause different effects in $\mathrm{P}$ and $\mathrm{K}$ uptake, depending on the absence or presence of $\mathrm{CaCO}_{3}$ in the peat substrate (lowered availability of nutrients). P. fluorescens can either block or allow the P uptake to the host plant, depending on whether the level of nutritional stress was sufficient to promote mycorrhization. Frey-Klett et al. (2007) demonstrated the potential of MHB to affect the N nutrition of host seedlings.

Although P. nigra var. salzmannii and $P$. halepensis Mill. are two calcicolous species, they show different strategies to cope with water and nutritional stress (Frouxa et al. 2002). Based on our results, it could be hypothesized that $P$. halepensis is more efficient than P. nigra in the use of their rhizospheric microorganisms.

Alterations of microbial populations in the rhizosphere may lead to quantitative and qualitative changes in the absorption of nu- 
trients by associated plants. Rincón et al (2008) found that the [Ps] inoculation may change the concentration of soil nutrient available for $P$. halepensis seedlings in the presence of different bacterial populations in the mycorrhizosphere. Additionally, ectomycorrhizal symbiosis may affect the bacteria community in the mycorrhizosphere (FreyKlett et al. 2005), which in turn can alter the nutrient availability (Simard et al. 2002), in particular N and P (Posta et al. 1994, Grayston et al. 1996).

\section{Water relations}

The regulation of the osmotic potential and the increase of the cell wall elasticity allow plants to maintain the cell turgor, thus tolerating negative water potentials in the soil and withstanding water stress (Villar-Salvador et al. 1997). In the present study, the osmotic potentials were not affected by any of the inoculations carried out (Tab. 1) Moreover, T. melanosporum inoculation has caused a slight (though not significant) increase in the elasticity of cell walls $(4.56$ $\mathrm{MPa}[\mathrm{T}]$ vs. 6.92 to $7.54 \mathrm{MPa}$ in the other treatments), as already noted by Domínguez et al. (2008).

Domínguez et al. (2006) reported that $T$. melanosporum can reduce the water deficit of the host plant during drought. Furthermore, Domínguez et al. (2008) observed that mycorrhization with black truffles under conditions of abundant water availability can cause an elastic adjustment of cell walls in $P$. halepensis seedlings, which may be a mechanism of resistance to water stress. Hormonal effects may also be involved in the water stress tolerance of plants inoculated with PGPR, since some bacteria can produce abscisic acid (ABA), a plant hormone produced in response to drought (Boiero et al 2007). Rincón et al. (2008) found that $P$. fluorescens Aur6 can enhance the water efficiency of associated forest species, but only when plants are subjected to a period of water stress.

In this study, the increased stiffness of cell walls may be related to the plant response to the flagellin produced by the bacteria. The presence of flagellin has been shown to induce stomatal closure (Melotto et al. 2006) and the modification of the protein content of cell walls (Vorwerk et al. 2004, Somerville et al. 2004). However, [Ps] inoculation did not cause significant decreases in cell elasticity in our study.

$P$. nigra does not usually produce $T$. melanosporum ascocarps, but only ectomycorrhizae. Some authors (García-Montero et al. 2007, Dominguez et al. 2012) suggested the use of black truffle mycorrhized seedlings as "carriers" of inocula of wild truffles for application in forestry truffle culture. In the present study, we observed the effects of co-inoculation [T. melanosporum x P. fluo- rescens] in $P$. nigra seedlings growing on substrate with $\mathrm{CaCO}_{3}$. Based on our results and those from similar study (Dominguez et al. 2012), we suggest that both inoculations can cause different effects in nutrients uptake and mycorrhizal colonization of seedlings, depending on the absence or presence of $\mathrm{CaCO}_{3}$. Mycorrhizal P. nigra seedlings do not seem particularly sensitive to addition of $P$. fluorescens. However, further studies are needed to better understand the effects of coinoculation [T x Ps] in seedlings of species symbiontic with the prized black truffle and to improve the environmental stress tolerance of forest plants through the co-inoculation of soil microorganisms.

\section{Acknowledgments}

This work was part of the project A/030 952/10 "Application of mycorrhizae in sustainable management of silvopastoral systems in the Mediterranean", PCI-AECID (Program of cooperation between universities and scientific research between Spain and Mediterranean countries, Spanish International Cooperation Agency for Development).

\section{References}

Agerer R (2012). Colour atlas of ectomycorrhizae $\left(15^{\text {th }}\right.$ edn). Ed. Einhorn-Verlay, Schwäbisch Gmünd, Munich, Germany.

Barbieri E, Guidi C, Bertaux J, Frey-Klett P, Garbaye J, Ceccaroli P, Saltarelli R, Zambonelli A, Stocchi V (2007). Occurrence and diversity of bacterial communities in Tuber magnatum during truffle maturation. Environmental Microbiology 9: 2234-2246. - doi: 10.1111/j.1462-2920. 2007.01338.x

Boiero L, Perrig D, Masciarelli O, Pena C, Cassán F, Luna V (2007). Phytohormone production by strains of Bradyrhizobium japonicum and possible physiological and technological implications. Applied Microbiology and Biotechnology 74: 874-880. - doi: 10.1007/s00253-006-0731-9

Bolton HJ, Fredickson JK, Elliott LF (1993). Microbial ecology of the rhizosphere. In: "Soil Microbial Ecology" (Metting FBJ ed). Marcel Dekker, New York, USA, pp. 27-63. [online] URL: http://www.cabdirect.org/abstracts/19931976429 .html

Bowman WD, Roberts SW (1985). Seasonal changes in tissue elasticity in chaparral shrubs. Physiologia Plantarum 65: 233-236. - doi: 10.11 11/j.1399-3054.1985.tb02388.x

Brule C, Frey-Klett P, Pierrat JC, Courrier S, Ge$\operatorname{rard} \mathrm{F}$, Lemoine MC, Rousselet JL, Sommer J, Garbaye J (2001). Survival in the soil of the ectomycorrhizal fungus Laccaria bicolor and the effects of a mycorrhiza helper Pseudomonas fluorescens. Soil Biology and Biochemistry 33: 1683-1694. - doi: 10.1016/S0038-0717(01)0009 $0-6$

Caravaca F, Alguacil MM, Azcón R, Parladé J, Torres P, Roldán A (2005). Establishment of two ectomycorrhizal shrub species in a semiarid site after in situ amendment with sugar beet, rock phosphate, and Aspergillus niger. Microbial Ecology 49: 73-82. - doi: 10.1007/s00248-0030131-y

Chanway CP (1997). Inoculation of tree roots with plant growth promoting soil bacteria: an emerging technology for reforestation. Forest Science 43: 99-112. [online] URL: http://www.ingentaconnect.com/content/saf/fs/1997/00000043/0000 0001/art00013

Cheung YNS, Tyree MT, Dainty J (1975). Water relations parameters on single leaves obtained in a pressure bomb and some ecological interpretations. Canadian Journal of Botany 53: 1342 1346. - doi: 10.1139/b75-162

Citterio B, Malatesta M, Battistelli S, Marcheggiani F, Baffone W, Saltarelli R, Stocchi V, Gazzanelli G (2001). Possible involvement of Pseudomonas fluorescens and Bacillaceae in structural modifications of Tuber borchii fruit bodies. Canadian Journal of Microbiology 47 (3): 264268. - doi: 10.1139/cjm-47-3-264

Deveau A, Palin B, Delaruelle C, Peter M, Kohler A, Pierrat JC, Sarniguet A, Garbaye J, Martin F, Frey-Klett P (2007). The mycorrhiza helper Pseudomonas fluorescens BBc6R8 has a specific effect on the growth, morphology and gene expression of the ectomycorrhizal fungus $\mathrm{Lac}$ caria bicolor S238N. New Phytologist 175: 743755. - doi: $10.1111 /$ j.1469-8137.2007.02148.x Domínguez-Nuñez JA (2002). Aportaciones de la micorrizacion artificial con trufa negra en planta forestal [Contributions of Black Truffle mycorrhization to iforest plants]. PhD thesis, Department of Silvopasciculture, Politechnic University of Madrid, Madrid, Spain, pp. 402. [in Spanish] Domínguez JA, Lopez C, Rodríguez Barreal JA, Saiz de Omeñaca JA (2003). Caracterización de rodales truferos en la comunidad valenciana [Characterization of forest stands producers of black truffle in Valencia (Spain)]. Ecología 17: 181-190. [in Spanish]

Domínguez JA, Selva J, Rodríguez Barreal JA, Saiz de Omeñaca JA (2006). The influence of mycorrhization with Tuber melanosporum in the afforestation of a Mediterranean site with Quercus ilex and Quercus faginea. Forest Ecology and Management 231: 226-233. - doi: 10.1016/ j.foreco.2006.05.052

Domínguez JA, Planelles R, Rodríguez Barreal JA, Saiz de Omeñaca JA (2008). The effect of Tuber melanosporum Vitt. mycorrhization on growth, nutrition, and water relations of Quercus petraea Liebl., Quercus faginea Lamk., and Pinus halepensis Mill. seedlings. New Forests 35: 159-171. - doi: 10.1007/s11056-007-9069-0

Dominguez JA, Martin A, Anriquez A, Albanesi A (2012). The combined effects of Pseudomonas fluorescens and Tuber melanosporum on the quality of Pinus halepensis seedlings. Mycorrhiza 22 (6): 429-436. - doi: 10.1007/s00572-01 1-0420-0

Frey-Klett P, Chavatte M, Clausse ML, Courrier S, Le Roux C, Raaijmakers J, Martinotti MG, Pierrat JC, Garbaye J (2005). Ectomycorrhizal symbiosis affects functional diversity of rhizo- 
sphere fluorescent pseudomonads. New Phytologist 165: 317-328. - doi: 10.1111/j.1469-8137.2 004.01212.x

Frey-Klett P, Garbaye J, Tarkka M (2007). The mycorrhiza helper bacteria revisited. New Phytologist 176: 22-36. - doi: 10.1111/j.1469-8137. 2007.02191.x

Frouxa F, Huca R, Ducreya M, Dreyerb E (2002). Xylem hydraulic efficiency versus vulnerability in seedlings of four contrasting Mediterranean tree species (Cedrus atlantica, Cupressus sempervirens, Pinus halepensis and Pinus nigra). Annals of Forest Science 59: 409-418. - doi: 10.1051/forest:2002015

Garbaye J, Duponnois R (1993). Specificity and function of mycorrhization helper bacteria (MHB) associated with the Pseudotsuga menziesii-Laccaria laccata symbiosis. Symbiosis 14: 335-344

García-Montero LG, Manjón JL, Martín-Fernández S, Di Massimo G (2007). Problems of using pines in Tuber melanosporum culture: soils and truffle harvest associated with Pinus nigra and P. sylvestris. Agroforestry Systems 70: 243-249. - doi: 10.1007/s10457-007-9052-y

Grayston SJ, Vaughan D, Jones D (1996). Rhizosphere carbon flow in trees, in comparison with annual plants: the importance of root exudation and its impact on microbial activity and nutrient availability. Applied Soil Ecology 5: 29-56. doi: 10.1016/S0929-1393(96)00126-6

Heinonsalo J, Frey-Klett P, Pierrat JC, Churin JL, Vairelles J, Garbaye J (2004). Fate, tree growth effect and potential impact on soil microbial communities of mycorrhizal and bacterial inoculation in a forest plantation. Soil Biology and Biochemistry 36 (2): 211-216. - doi: 10.1016/j.soilbio.2003.09.007

Jones MM, Turner NC (1980). Osmotic adjustment in expanding and fully expanded leves of sunlower in response to water deficits. Australian Journal of Plant Physiology 7: 181-192. - doi: 10.1071/PP9800181

Karabaghli C, Frey-Klett P, Sotta B, Bonnet M, Le Tacon F (1998). In vitro effects of Laccaria bicolor S238 N and Pseudomonas fluorescens strain BBc6 on rooting of derooted shoot hypocotyls of Norway spruce. Tree Physiology 18: 103-111. - doi: 10.1093/treephys/18.2.103

Martínez-Ferri E, Balaguer L, Valladares F, Chico JM, Manrique E (2000). Energy dissipation in drought-avoiding and drought-tolerant tree species at midday during the Mediterranean summer. Tree Physiology 20: 131-138. - doi: 10.10 93/treephys/20.2.131

Marulanda A, Barea JM, Azcon R (2006). An indigenous drought-tolerant strain of Glomus intraradices associated with a native bacterium improves water transport and root development in Retama sphaerocarpa. Microbial Ecology 52: 670-678. - doi: 10.1007/s00248-006-9078-0

Matthijs S, Tehrani KA, Laus G, Jackson RW, Cooper RM, Cornelis P (2007). Thioquinolobactin, a Pseudomonas siderophore with antifungal and anti-Pythium activity. Environmental Microbiology 9 (2): 425-434. - doi: $10.1111 / \mathrm{j} .14$ 62-2920.2006.01154.x

Melotto M, Underwood W, Koczan J, Nomura K, He SY (2006). Plant stomata function in innate immunity against bacterial invasion. Cell 126 : 969-980. - doi: 10.1016/j.cell.2006.06.054

Olsson PA, Jakobsen I, Wallander H (2002). Foraging and resource allocation strategies of mycorrhizal fungi in a patchy environment. In: "Mycorrhizal ecology" (Van der Heijden MGA, Sanders IR eds). Springer, Berlin, Germany, pp. 93-115.

Ouahmane L, Revel JC, Hafidi M, Thioulouse J, Prin Y, Galiana A, Dreyfus B, Duponnois R (2009). Responses of Pinus halepensis growth, soil microbial catabolic functions and phosphatesolubilizing bacteria after rock phosphate amendment and ectomycorrhizal inoculation. Plant and Soil 320: 169-179. - doi: 10.1007/s111 04-008-9882-z

Posta K, Marschner H, Rómheld V (1994). Manganese reduction in the rhizosphere of mycorrhizal and non mycorrhizal maize. Mycorrhiza 5: 119-124. - doi: 10.1007/BF00202343

Pirazzi R (1986). Mycorrhization of Pinus halepensis Mill. and Pinus nigra Arnold with Tuber melanosporum Vitt. and Tuber brumale Vitt. var. moscatum Ferry. Micologia Italiana 15 (1): 5-11.

Probanza A, Mateos JL, Lucas GJA, Ramos B, De Felipe MR, Gutierrez MFJ (2001). Effects of inoculation with PGPR Bacillus and Pisolithus tinctorius on Pinus pinea L. growth, bacterial rhizosphere colonization, and mycorrhizal infection. Microbial Ecology 41: 140-148. - doi: $10.1007 / \mathrm{s} 002480000081$

Reyna S (2007). Truficultura. Fundamentos y técnicas [Trufficulture. Fundamentals and techniques]. Ed. Mundi-Prensa, Madrid, Spain, pp. 688. [in Spanish]

Rincón A, Ruiz-Díez B, García-Fraile S, LucasGarcía JA, Fernández-Pascual M, Pueyo JJ, De Felipe MR (2005). Colonization of Pinus halepensis roots by Pseudomonas fluorescens and interaction with the ectomycorrhizal fungus Suillus granulatus. FEMS Microbiology Ecology 51: 303-311. - doi: 10.1016/j.femsec.2004.09.006

Rincón A, de Felipe MR, Fernández-Pascual M (2007). Inoculation of Pinus halepensis Mill. with selected ectomycorrhizal fungi improves seedling establishment 2 years after planting in a degraded gypsum soil. Mycorrhiza 18: 23-32. doi: 10.1007/s00572-007-0149-y

Rincón A, Valladares F, Gimeno TE, Pueyo JJ (2008). Water stress responses of two Mediterranean tree species influenced by native soil microorganisms and inoculation with a plant growth promoting rhizobacterium. Tree Physiology 28: 1693-1701. - doi: 10.1093/treephys/28. 11.1693

Ritchie G (1985). Root growth potential: principles, procedures and predictive ability. In: "Evaluating seedling quality. Principles, procedures and predictive abilities of major test" (Duryea M ed). Forest Research Lab, Oregon State University, Corvallis, OR, USA, pp. 93-106.

Rivera C, Blanco D, Oria R, Venturini ME
(2010). Diversity of culturable microorganisms and occurrence of Listeria monocytogenes and Salmonella spp. in Tuber aestivum and Tuber melanosporum ascocarps. Food Microbiology 27: 286-293. - doi: 10.1016/j.fm.2009.11.001

Robichaux RH (1984). Variation in the tissue water relations of two sympatric Hawaiian Dubautia species and their natural hybrid. Oecologia (Berlin) 65: 75-81. - doi: 10.1007/BF00384465

Sardans J, Rodá F, Peñuelas J (2006). Effects of a nutrient pulse supply on nutrient status of the Mediterranean trees Quercus ilex subsp. ballota and Pinus halepensis on different soils and under different competitive pressure. Trees 20: 619-632. - doi: 10.1007/s00468-006-0077-z

Scholander PF, Hammel HT, Bradstreet ED, Hemmingsen EA (1965). Sap pressure in vascular plants. Science 148: 339-346. - doi: 10.1126/science. 148.3668 .339

Silby MW, Cerdeño-Tárraga AM, Vernikos GS, Giddens SR, Jackson RW, Preston GM, Zhang XX, Moon CD, Gehrig SM, Godfrey SA, Knight CG, Malone JG, Robinson Z, Spiers AJ, Harris S, Challis GL, Yaxley AM, Harris D, Seeger K, Murphy L, Rutter S, Squares R, Quail MA, Saunders E, Mavromatis K, Brettin TS, Bentley SD, Hothersall J, Stephens E, Thomas CM, Parkhill J, Levy SB, Rainey PB, Thomson NR (2009). Genomic and genetic analyses of diversity and plant interactions of Pseudomonas fluorescens. Genome Biology 10 (5): R51. - doi: 10.1186/gb-2009-10-5-r51

Simard SW, Jones MD, Durral DM (2002). Carbon and nutrient fluxes within and between mycorrhizal plants. In: "Mycorrhizal ecology" (van der Heijden MGA, Sanders I eds). Springer, Berlin, Germany, pp. 34-74. - doi: 10.1007/9783-540-38364-2_2

Simpson DG, Ritchie GA (1997). Does RGP predict field performance. A debate. New Forests 13 (1-3): 253-277. - doi: 10.1023/A:100654252643 3

Smith SE, Read DJ (1997). Mycorrhizal symbiosis $\left(2^{\text {nd }}\right.$ edn). Academic Press, London, UK, pp. 605 .

Somerville C, Bauer S, Brininstool G, Facette M, Hamann T, Milne J, Osborne E, Paredez A, Persson S, Raab T, Vorwerk S, Youngs H (2004). Toward a systems approach to understanding plant cell walls. Science 306 (5705): 2206-2211. - doi: 10.1126/science. 1102765

Splivallo R, Fischer U, Göbel C, Feussner I, Karlovsky P (2009). Truffles regulate plant root morphogenesis via the production of auxin and ethylene. Plant Physiology 150: 2018-2029. doi: 10.1104/pp.109.141325

Tarka MT, Frey-Klett P (2008). Mycorrhiza helper bacteria. In: "Mycorrhiza" (Varma A ed). Springer-Verlag, Berlin Heidelberg, Germany, pp. 113-132.

Tyree M, Hammel HT (1972). The measurement of the turgor pressure and the water relations of plants by the pressure technique. Journal of Experimental Botany 23: 267-282. - doi: 10.1093/ $\mathrm{jxb} / 23.1 .267$

Tyree M, Jarvis PG (1982). Water in tissues and 
cells. In: "Encyclopedia of Plant Physiology, New Series, Vol. 12B, Physiological Plant Ecology II" (Lange OL, Nobel PS, Osmond CB, Ziegler $\mathrm{H}$ eds). Springer-Verlag, Berlin, Germany, pp. 36-77

Villar-Salvador P, Caña L, Peñuelas J, Carrasco I, Domínguez S, Renilla I (1997). Relaciones hídri- cas y potencial de formación de raíces en plántulas de Pinus halepensis Mill. sometidas a diferentes niveles de endurecimientos por estrés hídrico [Water relations and root formation potential in Pinus halepensis seedlings subject to different levels of water stress hardening]. Journal of the Spanish Society of Forest Science 4: 81-
92. [in Spanish]

Vorwerk S, Somerville S, Somerville C (2004).

The role of plant cell wall polysaccharide composition in disease resistance. Trends in Plant Science 9 (4): 203-209. - doi: 10.1016/j.tplants. 2004.02.005 